\title{
Jutustuse lagunemine ja stseeniline poeetika Ene Mihkelsoni proosas
}

\author{
INDREK OJAM
}

Artikli eesmärk on asetada Ene Mihkelsoni proosa modernistliku romaaniuuenduse uurimise teoreetilisse raami, mille üle on modernismiuuringute rahvusvahelisel areenil juba pool sajandit väideldud, kuid mida ei ole veel kasutatud eesti romaanitraditsiooni analüüsimisel. See puudutab modernistliku romaani poeetika peamist aspekti: jutustus e nõ rgen e mist ja selle asendumist kujutamisviisiga, mille nimetan Fredric Jamesoni eeskujul stseeniliseks kujutamiseks. Sissejuhatuses käsitlen lähemalt selle määratlemisvõimalusi. Artikli laiem eesmärk on Mihkelsoni loomingu analüüsiga panustada eesti modernistliku romaani poeetika süstemaatilisse uurimisse.

Modernistlikku romaani seostatakse üleüldise kujutamise kriisiga Euroopa kultuuris (Lewis 2011: 1). Islandi kirjandusteadlane Ástráður Eysteinsson (1990: 220) on märkinud, et modernistlikud võõritavad tekstid tõusevad esile hetkel, mil realistlik kirjutus ei suuda enam uue, sekulariseerunud maailma vastuolusid adekvaatselt kujutada ja tähelepanu pöördub endise normaalse korra katkestustele ja häiretele. See modernismi väljakutse realismile on Eysteinssoni sõnul enim esiplaanil jutustuse kategooria sisulises muutumises. Modernismi üheks definitsiooniks võikski olla vastupanu selgelt piiritletavatele, reaalsust kujutavatele lugudele, mille funktsiooni ja tähendust ühiskonnas saaks lihtsalt ja pragmaatiliselt määratleda (Eysteinsson 1990: 187). Eysteinsson seda küsimust põhjalikumalt edasi ei arenda. Seda on aga püüdnud teha Stephen Kern (2011) modernistliku romaani ajaloolisele tekkele pühendatud raamatus, milles ta võrdleb suurt hulka peamiselt 1900.-1940. aastatel kirjutatud inglise, prantsuse ja saksa keeleruumist pärinevaid kanoonilisi teoseid. Tema põhiline küsimusepüstitus on, kuidas õõnestavad need teosed sajandivahetuse Lääne-Euroopa keskklassi väärtuste hierarhiaid, mis on kinnistunud domineerivatesse autoriteetsetesse narratiividesse (ingl master narrative) ehk ajaloolase Allan Megilli sõnastuses mõne ajaloosegmendi autoriteetsesse seletusse (Kern 2011: 9). Need hõlmavaid seletusi pakkuvad lood jaotab Kern (2011: 9-20) järgmistesse kategooriatesse: 1) personaalne narratiiv ehk sellise isiku teekond, keda juhivad liberaalsed ja eetilised põhimõtted; 2) abielu- või armunarratiiv paari moodustumisest; 3) perekonnanarratiiv; 4) linnanarratiiv, mis seostub edupüüdlustega värskelt tekkinud suurlinnades; 5) rahvuslik narratiiv, mille keskmes on isiku kuulumine uude suurkogukonda ja selle kogukonna vabaduseotsing; 6) impeeriuminarratiiv, mis kujutab koloniaalvalduste laienemist ja integreerimist emamaaga; 7) kapitalistlik narratiiv rikkuse ja heaolu kasvust; 8) liberaalne narratiiv valgustuse ideede ja väärtuste võidule pääsemisest; 9) religioosne narratiiv halastusest ja lunastuse saabumisest; 10) kunstnikunarratiiv. Neid kategooriaid enim mõjutanud vormiuuenduseks 
nimetab Kern (2011: 66) tugeva loo (ingl strong plot) hülgamist, mis on toonud kaasa sidususe ja usutavuse muutuse kõigis kategooriates.

Frederik Tygstrup märgib oma artiklis „Vaikelu. Ruumi kogemine modernistlikus proosas" (2007) tabavalt, et moodsas romaanis on elu ja narratiivi sümmeetria justkui rebenenud: traditsiooniliselt loo teenistuses olnud kirjeldused ja stseenid hõlmavad romaani kompositsioonis aina autonoomsema osa, mistõttu ainuüksi narratiivi dünaamikast lähtuvad tõlgendused ei ole usaldusväärsed (2007: 253). Tygstrup rõhutab kahe erineva tekstitüübi poeetilist koostoimet: modernistlik romaan nii registreerib igapäevaseid tajusid kui ka jutustavale kujutamisele omaselt asetab need inimliku ajataju koordinaatidesse, mida kontrollib mõni põhjuslik skeem. ${ }^{1}$ Modernistlik stseen, mis pole enam realismi traditsioonist tuttav kirjeldus, „moodustab omaette kujutise, mis skematiseerib intuitsioone ja nendest ammutatud elementide seoseid, see ei ole visualiseeritud pilt imaginaarsest reaalsusest, vaid autonoomne viis reaalsust modelleerida, mis mõnikord langeb kokku visuaalsusega, mõnikord aga mitte" (Tygstrup 2007: 259-260). ${ }^{2}$ Tygstrup kirjeldab niisiis uut kujutamisviisi, mis ei lange kokku jutustusega, kuid mis ei ole ka enam äratuntav kirjeldusena. Selles seisnebki siinses artiklis uuritav probleem: nii jutustamine kui ka kirjeldustest välja kasvanud modernistlik stseeniline kujutamine jäljendavad ehk representeerivad reaalsust, aga põhimõtteliselt erineval moel. Jutustuse olemuseks on põhjuslik seletus ehk maailma seletamine ühiskondliku konventsiooni alusel. Modernistliku romaani poeetika ei avaldu ainult jutustuse kategooria kaudu, arvesse tuleb võtta selle suhtes osaliselt autonoomset kujutamisviisi, mis ei sisalda jutustusele omast põhjuslikkust.

Dora Zhang (2013: 3) sedastab modernistliku romaani kirjeldusi uurivas doktoritöös, et XIX sajandi realistlikud kirjeldused põhinesid veel objektide kõrvutamisel, visuaalse mulje kannatlikul ülesehitamisel, kuid sajandivahetusel hakati neid kirjeldusi tajuma naiivse või mitteautentsena. Zhangi järgi ei toonud see kaasa kirjelduste vähenemist tekstis, vaid tähelepanu nihkus uutele tajumisviisidele (vt ka Castle 2015: 6). Eestikeelsele lugejale seostub sõna kirjeldus tõenäoliselt realistliku romaani traditsiooniga: näiteks looduse, samuti inimese loodud keskkondade ja interjööride meelelise kujutamisega. Kuid modernismis tähendab jutustuse nõrgenemine tihti refleksiivset pööret teadvuse toimimise poole ja suuremat esseistlikkust (Mazzoni 2017: 314-318; viimase ilmselt parimaks näiteks on Robert Musili romaan „Omadusteta mees”). Selline tekst ei pruugi enam seostuda sõna kirjeldus harjumuspärase tähendusega, aga samal ajal ei ole korrektne nimetada seda jutustavaks eeltoodud definitsiooni järgi: jutustuse olemuseks on p õ hju s lik s e l e t u s.

Jutustamise eri viisid ning põhjuslikkuse astmed on narratoloogia keskne uurimisobjekt. Juba terminit narratiivsus võib mõista nii kahevalentsena (tekst kas on narratiivne või mitte) kui ka skaalal muutuvana (tekstid on vähem või rohkem

\footnotetext{
${ }^{1}$ Gregory Castle (2015: 7) viitab ilmselt samale lahknevusele, kui kirjutab: „Representatsioon leidub ka kõige resoluutsemalt antimimeetilistes romaanides."

${ }^{2}$ Tygstrup osutab asjaolule, et siin käsitletud mittejutustav ehk stseeniline kujutis modernistlikus romaanis, mille mõnd avaldumisvormi on nimetatud ka "teadvuse voolu tehnikaks", ei ole midagi kujutluslikku, mida saaks taandada kriitikas levinud terminiga mõne „tegelase peas toimuvaks", vaid tegelaste elumaailma afektiivse reaalsuse realistlik kujutis.
} 
narratiivsed) (Abbot 2009: 309). Narratoloog Marie-Laure Ryani (1992, 2006, 2007) meelest pole mõtet defineerida narratiivi täpselt ja vastuoludeta, vaid kasutada tuleks prototüüpsete tunnuste alusel määratlust, milles mõni tunnus on rohkem esil ning mis võimaldab suuremate vastuoludeta eristada rohkem ja vähem narratiivseid tekste. Olen seisukohal, et jutustuse tähendus ei seisne pelgalt kestuses ja muutuses ning ka Ryani (1992: 371) määratluse tähtsaim osa on narratiivi tausta moodustav inimlike motiivide ja suhete võrgustik. Minimaalse, kuid tervikliku loo objektiks on igal juhul mingisugune implitsiitne, põhjuslikkust sisaldav (eelteoreetiline) arusaam inimkäitumise ja -elu kohta ${ }^{3}$ (Mazzoni 2017: 48). Lahknevust jutustuse ja n-ö jutustuse sotsiaalse semantika suhtes tumma, stseenilise näitamise vahel on käsitlenud ka klassikaline ehk strukturalistlik narratoloogia, seda küll samuti jutustuse ja kirjelduse terminite kaudu. Gérard Genette (1983) on siinses artiklis stseenina määratletavat tekstiosa nimetanud kirjeldavaks pausiks. Paus on Genette’i narratiivi temposüsteemis ellipsi vastand: ellipsiga saab lühikese jutustamisajaga (nt lõigu vahetus) läbida kui tahes suure osa looaega, samal ajal kui paus võimaldab jutustamist aina jätkata, hoides looaega paigal (Genette 1983: 93-95). Teisal rõhutabki Genette (2018: 72-73), et mittejutustavat tekstiosa, nagu kirjeldus, peaks vaatlema igal juhul jutustuse osa või funktsioonina. ${ }^{4}$ Niisugune hoiak on omane kogu narratoloogia valdkonnale, mille uurimisobjekti piiritleb alati jutustuse mõiste ning mis on vähem efektiivne staatiliste tekstide tähenduse eritlemisel ega võimalda eraldi uurida jutustusega lõdvemalt seotud kujutisi. Samuti ei sekku siinse artikli probleemipüstitus tuntud mimeesi ja diegeesi ehk jutustamise ja näitamise (Genette 2018: 66-71; Klauk, Köppe 2013) eristusse, mis puudutab pigem kunsti meediume ja žanrikonventsioone. Lugu on võimalik edukalt jutustada ka näidates, samal ajal kui stseen märgib puhast, loo sotsiaalse põhjuslikkuse mõõtmest vaba näitamist, mida on vaja juba uuel tasandil tõlgendada.

Jutustuse nõrgenemine ja stseeni domineerimine on palju käsitletud poeetikafenomen, mida ei ole aga täpselt määratletud ega ole selge ka selle ajalooline teke. Seetõttu on esmatähtis valida selle uurimiseks meetod, mis kasutaks semiootilises plaanis paindlikult modelleerivaid, mitte liiga spetsiifilisi (nt Tygstrupil ja Zhangil visuaalsusega seonduvad) termineid, ning mis ei mõistaks kohe teksti mõne eelduspärase jutustuse žanri osana (nagu juhtuks Genette'ist lähtudes).

Selleks pakub eeskuju Fredric Jamesoni raamat „Realismi antinoomiad” (2013). Narratoloogiliselt toetub Jameson moodsa romaani poeetikat piiritlevate jutustuse (mille tuumana kasutab ta prantsuskeelset terminit récit) ja stseeni eristusele. Récit ehk lihtsalt lugu koondab eelmodernset päritolu, nt religiooni ja rahvaluule tradit-

\footnotetext{
${ }^{3}$ Juba Aristotelese traktaadi „Luulekunstist” tragöödiakäsitluse aluseks on arusaam sotsiaalsest põhjuslikkusest, mis on sõnastatud paratamatuse ja tõenäosuse terminites: „Lihtsaks nimetan ma tegevust, mille toimumisel pideva ja ühtsena, nagu on määratletud, toimub muutus ilma pööraku ja äratundmiseta, põimituks aga sellist, kus muutus on koos kas äratundmise, pööraku või mõlemaga. Need aga peavad tekkima loo kokkuseadest endast, nii et nad toimuksid tulenedes eelnevalt toimunust, kas siis paratamatult või tõenäolisusele vastavalt [---]." (Aristoteles 2003: 30-31, vt ka Ricoeur 1990: 178)

${ }^{4}$ Selle põhjuseks nimetab ta seda, et pole olemas ainult kirjeldavaid žanre (mis tuleneb omakorda sellest, et narratiiv on määratletud iga väiksemagi muutuse representatsioonina).
} 
sioone, mille lugudel on algus ja lópp ning nende sisuks on inimese saatus. Jameson toetub Walter Benjamini esseele „Jutustaja”, kui rõhutab, et indiviidi loo tähenduslikuks muutumise juures on otsustav osa surmal: inimelu sündmused muutuvad ainukordseks elu lõplikkuse perspektiivis (Jameson 2013: 18-21). Sellisele loole vastandab Jameson igavese oleviku: kuni kirjutav subjekt on elavate kirjas, on paratamatu tema viibimine kehaliste aistingute keskel, mille taju on enne narratiivse keeletegevuse sekkumist olevikuline. ${ }^{5}$ Nendele kahele ajamõõtmele - minevikust läbi oleviku tulevikku kulgev aeg ja keha igikestev olevik - lisandub Jamesoni teoorias paralleelne emotsioonide ja afektide eristus, mis käsitleb probleemi, kuidas keeleline tähistusprotsess muudab kehalist olevikku sellesse lõikudes. Afektid on loomult mittepersonaalsed ja mittekeelelised kehalised tunded. Emotsioonid on olemuslikult keelelised, nimetatud (Hegeli ja Lukácsi traditsioonis „asjastatud”) tunded, mis moodustavad binaarse (õnnelik-õnnetu, kurb-rõõmus jne) ja allegoorilise tähenduste süsteemi: emotsioonid ilmnevad alati mingite juba tähenduslike sündmuste, reaktsioonide korral. Afektid liiguvad küll kehade vahel, kuid ei võimalda märgilist suhtlust ning on määratletavad pigem kehaliste intensiivsustena. ${ }^{6}$ Emotsioonid sekkuvad nimetamise käigus afektidesse ja muundavad neid, asetades sündmused tähenduslikku konfiguratsiooni. Sellest omakorda moodustub isiku identiteet ehk elu lugu, mis saab jutustuse aluseks (vt Jameson 2013: 44).

Nende eristuste toel jälgib Jameson, kuidas allegooriapõhised inimkogemust seletavad märgisüsteemid XIX sajandil moderniseerumisprotsessi vältel lagunevad ja asenduvad kujutamisega, milles on esiplaanil nn üldistunud kehalised tundmused, mis ei viita enam ühelegi selgepiirilisele väärtussüsteemile. Selle murrangu alguspunktiks on Flauberti looming ning see tähendab, et kujutamisel ei juhinduta enam tegelaste saatusest ehk mineviku-oleviku-tuleviku teljel kulgevast jutustusest, vaid kujutamisobjektiks on keha olevikulises aistilises tegelikkuses (Jameson 2013:25, 28), mis ei paku ajendit jutustuseks. See, et romaanid kätkevad konkreetsete jutustuste kõrval üha enam eelpersonaalset afektide ja tajude valda, vastab üldisele inimkogemuse suundumusele: süveneb tähenduse ja kehalise kogemuse lahknemine (Jameson 2013: 37). Modernistlik romaan võtab selle representatsioonilise väljakutse vastu ja selle tulemusena domineerib üha enam jutustuse eri vormide suhtes autonoomne kirjeldus, mida Jameson nimetab stseeniks. Stseeni mõiste eeliseks on, et see juhib tähelepanu kõrvale kirjeldusega seostuvalt visuaalsuselt ja objektiivsuselt, mis on kirjandusliku realismi pärand. Ka järgnev Ene Mihkelsoni romaanide tõlgendus näitab, et jutustusest irduv stseen võib, aga ei pruugi olla kirjeldav harjumuspärases tähenduses. Nimetangi edaspidi stseeniks või stseeniliseks kujutamiseks jutustuse

\footnotetext{
${ }^{5}$ Jamesoni käsituses moodustavad selle kaksikjaotuse kirjandusloolise tausta J-P. Sartre'i vabadusefilosoofia ning kriitika Guy de Maupassanti ja François Mauriaci kohta. Sartre oli seisukohal, et kirjandus, eriti romaan peaks suutma kujutada eelkõige inimese radikaalset vabadust ja otsustamishetkede talumatut agooniat kui elu põhilist kogemust. Selle jaoks on sobimatu juba lõppenud sündmustega jutustamissituatsioon nagu Maupassantil ja jumalik, kõiketeadev vaatepunkt tegelaste olukorrale nagu Mauriacil (Jameson 2013: 18).

${ }^{6}$ Selle eristuse levimisel kirjandus- ja kultuuriteoorias on kõige suurem kaal Brian Massumi esseel „Autonomy of affect” (2002), millele Jameson olulisel määral toetub. Massumi afektiteooria kriitikat vt nt Breger 2017: 240-241 ja Sha 2017.
} 
pidevast kahtluse alla panekust sündivat olevikulist, kehalisele kogemusele osutavat tekstiosa. Stseenilisusele vastandan loo ja jutustuse mõisted, mida kasutan artiklis sünonüümidena. Vastandus on eelkõige metodoloogiline ja annab alternatiivse võimaluse kirjeldada Mihkelsoni proosa poeetilist mõõdet.

Varem olen Jamesoni meetodi põhjal uurinud stseenilist kujutamist Madis Kõivu (Ojam, Tomberg 2016) ja Mati Undi (Ojam 2020) loomingus. Mihkelsoni proosa poeetika värske tõlgendus võiks esile tuua teoste esteetilise mõju allika, mis on kõnetanud paljusid lugejaid, hoolimata nende teoste hägususest või raskepärasusest. Stseeni ja jutustuse eristus näib selleks kõige paremini sobivat. Keskendun romaanidele „Ahasveeruse uni” (2001) ja „Katkuhaud” (2007), milles stseeniline kujutamine domineerib jutustuse üle, kuid viitan ka teistele Mihkelsoni teostele, milles võib seda tendentsi märgata, samuti autori metatasandi refleksioonidele samal teemal.

\section{Interpersonaalne pinge ja Mihkelsoni tuumstseen}

Esimene ja tähtsaim lugemismulje seoses Mihkelsoni proosa poeetikaga on see, et tema romaanides e i juhtugi eriti midagi, kui sündmuseks pidada selget murrangut peategelase sotsiaalses elus. Suurem osa „Korterist”, „Nime vaevast”, „Ahasveeruse unest” ja „Katkuhauast” koosneb üksteisele järgnevatest episoodidest, milles arutatakse erinevate faktide tegelikkuse, nende toimumise tõenäosuse või filosoofiliselt isegi sündmuste võimalikkuse tingimuste üle. Mihkelsoni retseptsioonis on korduvalt rõhutatud - viimati Jan Kaus (2020: 50) ja Henrik Sova (2020: 555) -, et tema romaanide keskne ja tähtsaim probleem ongi teadmatus. See teadmatus väljendub ka teksti poeetikas. Maia Tammjärv (2012: 59-62) märgib, et „Ahasveeruse unes" ei jõua tekkida usaldusväärset jutustust. Seetõttu kasutab ta Mihkelsoni poeetika kirjeldamiseks Gregory Currielt pärinevat püsiva ebausaldusväärsuse terminit (Tammjärv 2012: 51-52). Tammjärve uurimuse uudne panus on tähelepanek, et Mihkelsoni tekstis (ja ka nt sealsamas analüüsitud Madis Kõivu „Aknas”) tekkiv ebausaldusväärsus erineb näiteks petliku ja lahtise lõpuga detektiiviloo ebausaldusväärsusest (vt ka Sova 2020: 563). Jaak Tomberg (2011: 116-117) leiab, et Mihkelsoni poeetika kõige iseloomulikum tunnus on piiride hägustumine teksti igal tasandil: nii minajutustaja omailmas, jutustamissituatsioonis kui ka ajalistes piirides ja erinevates tõeversioonides, samuti kirjelduse ja kõne, luule ja proosa vahel ning isegi tegelaste identiteetides. Tomberg viitab omakorda Virve Sarapiku (2005) käsitletud arheloo mõistele. Arhelugu või „konkreetsustetagune totaalsus” (Tomberg 2011: 116-117) näib moodustuvat neist "probleemidest ja intensiivsustest”, mida autor endaga kaasas kannab, kuid mis ilmnevad igas teoses eri kujul. Sarapik (2005: 814) kirjeldab Mihkelsoni poeetikat kui põimingut „nappidest stseenidest, seikadest, mälupiltidest, unenägudest ja mõtisklustest ja taaskorduvatest toimingutest". Aija Sakova (2020: 40) lisab, et „Katkuhauas” „vahelduvad märgistamata otsekõne, siirdkõne ja esseistlikud-filosoofilised tekstilõigud minevikuga tegelemise kohta" (vt ka Rein 2010: 208). Viimane tähelepanek on oluline ka käesolevas probleemipüstituses, kuna esseistlik- 
filosoofiline arutlus, mida Mihkelsoni teostes rohkelt leidub, ei sobitu areneva jutustusega, kuid põhjalik tõlgendus peaks ka seda tekstikihti arvesse võtma.

Niisiis väljendab Mihkelsoni poeetika eelkõige teadmatuse seisundit ja ebausaldusväärsust teose sündmuste suhtes, hajutades ning seades pidevalt kahtluse alla tekstis tõmmatud piire. Mihkelsoni proosa sisaldab väga erinevaid lausungi- ja tekstitüüpe, mis moodustavad heterogeense koosluse ja on suures osas vasturääkivad. Ainult mõned väiksemad lõimed annavad edasi tavapärast jutustust. Vastuolulised lõimed asetsevad Mihkelsoni tekstis üksteise kõrval enesestmõistetavalt, aeglustades lugemise tempot ja juhtides alatasa tähelepanu loo juurest refleksioonile (inimelust) jutustamise ja kujutamise võimalikkuse üle. Siinses tõlgenduses koondan Mihkelsoni proosa iseloomulikud aspektid - piiride hajuvus, jutustajahääle püsiv ebausaldusväärsus ja metanarratiivsed kommentaarid - tuumstse eni mõiste alla. See on romaanide poeetiline dominant, mis juhatab jutustuse nõrgenemise ja stseenilise kujutamise probleemi juurde.

Tuumstseen kujutab endast Mihkelsoni romaanide tüüpilist kohtumiste ja kõneluste situatsiooni, millest võrsuvad minajutustaja jaoks ühelt poolt potentsiaalne konflikt ning teiselt poolt uue mõistmise ja teadmise võimalus. Näiteks võib „Katkuhaua" ülesehitust kirjeldada proua Binta, Kaata ja Sannaga kohtumiste jadana, mida raamib algava pronkssõduri skandaali kujutus; „A Ahasveeruse unes” leiavad aset kohtumised ja telefonikõned Vilma ja Kaarliga, „Nime vaevas” Aadu ja Kudri Elliga.

„Katkuhauas” on tuumstseen ehk kõige selgem ja seisneb eelkõige jutuajamistes tädi Kaataga tema kodus. Kaata hoolitses minajutustaja eest stalinistliku terrori ajal, kui peategelase vanemad varjasid end metsas. Kaata nimi esineb „Katkuhauas” esimest korda teises peatükis, kui dialoog Arpi-nimelise tegelasega tuletab minajutustajale meelde, et "NIIMOODI RÄÄKIS KORD KAATA KA MINUGA” (Mihkelson 2007: 11). Versaalis lausega aktiveeritakse lugeja tähelepanu ja koondatakse see stseenile, mis saab romaanis peamiseks. Kolmandas peatükis tekib minajutustajal üht sugulast (kellele viidatakse lihtsalt kui „naisele”) külastades tahtmine minna Kaatat vaatama. Minajutustaja on Kaataga juba arutanud muu hulgas ka minevikusündmusi: „Kaata oli ainus, kelle küsitlemine oli mul jäänud poolikuks. Temaga toimus alati midagi, ta rääkis oma elujuhtumeist väga mitmel viisil, nii et ma väsisin lõpuks kuulates alati ära ega kärsinud kunagi seda viimset põhja püüda." Kuid tõeline kohtumine temaga on alles ees, millele jutustaja kohe ka viitab: „Minu järgmine sihtmärk oli nüüd Kaata." (Mihkelson 2007: 22) Neljandas peatükis jõuab jutustaja tõepoolest Kaata juurde koju, kirjeldades teda: „Kaata oli kui holokausti filmides nähtud vang - poole lühem, justkui kokku kuivanud, nägu väike ja kipras, mitu peakatet üksteise otsas: valge barett kõige all, siis sirelililla villane rätik ja kõige peal tumepruun kootud müts" (Mihkelson 2007: 31).

„Ahasveeruse unes” tekib minajutustaja ema Vilma lähedalolekust sarnane olukord, mis tuleneb esimeses isikus jutustaja pidevast vaheldumisest kolmanda isikuga. Vilmat ei nimetata küll romaani esimestes peatükkides, kuid tekstist selgub, et asesõnade vaheldumisega on mängu toodud just tema isik. Jutustajaperspektiivide muutlikkus loob küll sisulise segaduse, kuid see hoiab ka alal vestluskaaslast, keda kolmandas isikus nimetatakse. 
Võib öelda, et Kaataga kohtumise ja vestlemise stseen ei alga ega lõppegi „Katkuhauas" täielikult, vaid see moodustab tsooni, kuhu jutustus aina naaseb või tagasi langeb. Loomulikult lisandub peatükkide kaupa aina uut informatsiooni, mis avab lugejale minajutustaja suhte Kaataga. Kuid Mihkelsoni eripära on kirjutada nii, et Kaata perspektiiv kui Teise teadmine ja pidev kohalolu läbib jutustust. Selle Teise teadvuse kujutamisega seostuvad unenäod ja metafüüsilised arutlused subjektiivsuse üle, mis on teksti põimitud eesti kirjanduses harva esineva sujuvusega. Samamoodi ei alga ega lõppe selgel viisil „Ahasveeruse unes” Vilmaga läbirääkimiste stseen ning mis tahes lõik on siirde abil või minalt temale ümber lülitudes muudetud selle lõputu vestluse osaks.

On muidugi oluline märgata, et „Ahasveeruse unes” asesõnade vaheldumine ei puuduta ainult minajutustaja ja tema ema vaatepunkti, vaid ka (vähemalt) kedagi kolmandat, mida näitavad sellised laused nagu „[--- $[$ ema tahab talle enne surma selle saladuse ära rääkida, miks ta on terve elu oma tütart vältinud” (Mihkelson 2001: 178). Siinkohal kerkib esile Mihkelsoni proosa retseptsioonis oluline (Sakova 2018, 2020) tunnistamise teema, mis poeetika tasandil väljendubki asesõnade vaheldamisena. Niisugune kirjutus tekitab spiraalse tunnistuse ahela, milles juhtunule vaatavad alati tagasi subjekt, kes on pealtnägija ja kes toimunust nüüd tunnistust annab, ja keegi, kes seda kuulab ja saab omakorda edasi rääkida. Erinevate tunnistuste spiraal ei jõua aga välja selleni, kes võiks öelda juhtunu kohta viimase sõna. Mihkelsoni tuumstseen osutab võimatule hetkele, mil need tunnistavad teadvused viibivad korraks ,ühel lainel”.

Eeltoodud aspektid on üks põhjusi, miks on Mihkelsoni romaanidest raske konkreetset lugu meelde jätta (Hennoste 2003). Asesõnade muutumisest tuleneb lausungi grammatilise subjekti pidev nihkumine, mistõttu ei saa teosest välja lugeda ühegi kindlapiirilise isiku kronoloogilist lugu. On aga oluline näha tegelas(t)e subjektiivsuse moodustumise seost jutustuse ja stseeni vahekorraga romaani narratiivis üldiselt. Tegelaste individualiseerimatus ehk nende lahtine identiteet sündmuste voolusängis ei lase romaanitekstist eristada ka mõnd kujunemislugu. Selle asemel kõigub jutustus erinevate isikute ja aegade vahel, mis ristuvad tuumstseenis. Mihkelson õonnestab pidevalt lugemisel tekkivat, mõne lõpliku identiteedi moodustumise ootust ja paiskab tekstis esitatava aja minajutustaja kehalisse olevikku, milles too küsitleb oma võõrustajat või kaaslast. ${ }^{7}$

\footnotetext{
${ }^{7}$ Sama fenomeni kirjeldab analüütilise keelefilosoofia vaatepunktist Henrik Sova, kelle järgi seisneb Mihkelsoni romaanide poeetika selle esiletoomises, et ajaloolise tegelikkuse kujutamine toimub alati pragmaatilisel, mitte inimlikest kokkulepetest sõltumatu tegelikkuse olemasolu eeldaval representatsionistlikul alusel (Sova 2020: 566-567). Nõustun selle väitega poeetika kirjeldamise tasandil. Ka minu näited siin artiklis selgitavad eelkõige seda, et Mihkelsoni romaanide tuumstseen toimub stseenilises olevikus, mis kipub laiali valguma ja domineerima jutustuse üle (mis eri perspektiivide tõttu aina ähmastub). See osutab tõigale, et mineviku tegelikkus sõltub olevikulise intersubjektiivse situatsiooni tegelikkusest. Tõe otsimine toimub olevikulises stseenis, mitte mõnes narratiivses, mineviku-oleviku-tuleviku teljel kulgevas jutustuses. Mulle tundub aga, et Sova käsitlus eeldab semantilise pragmatismi programmi kui filosoofilise realismi ja ajalookonfliktide „leevendaja” eelnevat omaksvõttu. Mihkelsoni tekst näib tõepoolest ikka ja jälle ütlevat, et minevikku ,järele kontrollida” ei saa, ja jõuab ajaloolise tõega seoses perspektivismi tõdemiseni, millest võivad aga minu arust avaneda ka mõned teised filosoofilised positsioonid.
} 
Tegelaste ebastabiilsus on niisiis Mihkelsoni romaanides üks tähtsamaid stseenilisuse allikaid. Järgnevalt käsitlen lähemalt kohtumise tuumstseeni toimimist ja jutustuse asetumist stseeni-aega, viidates kahele aspektile, mida on võimalik eritleda iga romaani poeetika juures: ruumi kujutamine ja sündmus.

\section{Ruumi kujutamine ja stseenilisus}

Ruumi kujutamise all pean silmas seda, kui täpselt on romaanides antud tegevuskoht ning kuidas see mõjutab jutustust ja selle kaldumist stseenilisse kujutamisse. Sarapik (2005: 815-816) on täheldanud, et Mihkelsoni romaanide tegevusruum on tänu kohanimedele ja ruumiviidetele realistlik ning kergesti jälgitav. Äratuntav topograafia ja toponüümia pakuvad muidu vastuolulise teksti lugejale pidepunkte, mis üheskoos hõlbustavad lugemist. Üldjoontes ei kirjelda Mihkelson füüsilisi kohti pikkade terviklike lõikudega, mis tooksid esile detailirohke ja areda ruumi. See tähendab ka, et ruumikirjeldus ei moodusta pikka autonoomset tekstiosa, mis lõikuks jutustusse katkestava kiiluna. Ruumikujutus on pigem vihjeline ja napp. Ruum on Mihkelsoni tekstis tavaliselt seotud mõne tegelase või sündmusega, kuid see seos ei ole harilikult allegooriline, seega ruumid ja objektid ei muutu millegi teise (näiteks tegelase saatuse) kujutiseks.

„Katkuhauas” on tähtsaim koht, kus ruumi ja tegelase vahel tekib seos, Kaata maja, kus möödub (vähemalt implitsiitselt) mineviku üle arutledes suur osa romaani ajast. Kaata maja korratus torkab juba eemalt silma ja see on minajutustajale märk, et midagi on valesti (Mihkelson 2007: 23). Kaata nägu ilmub külalisele kõigepealt välisukse aknaruudus, sealt heidetud pilk jääb aga minajutustajat kummitama ja selle vaatepildi juurde naastakse tekstis korduvalt (Mihkelson 2007: 31, 33, 43, 138). Kui mainisin, et „Katkuhauas” ei alga ega lõppe kohtumine Kaataga selgelt piiritletud viisil, siis see kehtib ka Kaata kodus viibimise kohta. Näiteks 17. peatüki alguses meenutab minajutustaja kokkusaamisi koduküla inimestega ja nende küsitlemist: „Päevade kaupa Kaata juures istudes tulid mulle tihti meelde kodukülast pärit vanainimesed. Nende mälestused mõjusid mulle kui i g a v e n e ol e vi k, mis Kaata ja minu vestlustundidesse sisse pressis, nii et vahel unustasin Kaata kohalolugi." (Mihkelson 2007: 226, minu sõrendus - I. O.) Seejärel kirjeldatakse neid kokkusaamisi ja lugejal võib jääda mulje, et need ongi peatüki sisuks. Kuid järsku selgub, et minajutustaja on kogu aeg viibinud Kaata juures:

Kui Kaata äkki rääkima hakkab, võpatan nii nähtavalt, et tädi jääb mind üllatunult vaatama. [---] Minuga on juhtunud see, mis tavaliselt Kaataga: ma olen ühes ajavahemikus mitmes kohas olnud ühel ja samal ajal korraga. (Mihkelson 2007: 235)

Sarnane efekt, kuid ilma minajutustaja eksplitsiitse kommentaarita, tekib „Ahasveeruse une" neljandas ja viiendas peatükis, mis moodustavad küll tervikliku, kuid lugedes aina mitmeti mõistetavamaks muutuva episoodi. Neljanda peatüki sisu on lühidalt järgmine: peategelasele tuleb külla ema, kellega tuleb jutuks hiljuti toimunud 
sugulaste haudade külastamine. Nende läbisaamisse siginevad vaenulikud noodid, sest ema süüdistab tütart nõiaks olemises. Tütar jookseb selle peale korterist välja koridori ja jääb sinna vihasena ja meeleheitel istuma, kusjuures uks langeb sneprisse. Ootamatult ütleb neljanda peatüki lõpulause: „Paar aastat hiljem tuli mulle meelde, et ma pole elu seeski sugulaste haudadel käinud, ja siis selle retke ette võtsingi” (Mihkelson 2001: 42). See näib kinnitavat, et surnuaial ei käinud tütar. Viiendas peatükis jutustatakse surnuaial käimise lugu uuesti ja selgub, et käijaks oli ema, kes leidis oma venna Alfredi haua. Juttu sigineb sünge noot, ema mainib surma kohtamist ja komistamist ühele hauaplaadile, mis osutub ta onu omaks. Minajutustaja, kes seda juttu kuulab, otsustab hirmuõhustiku lõpetada ja küsib, kui palju oli emal küünlaid kaasas. Peatükk lõpeb ema vastusega: „Viisteist, viisteist, kisas ta, tormas magamistuppa ja tõmbas voodis tekigi üle pea" (Mihkelson 2001: 46). See lause osutab järsult kahe naise kohtumise kohale, mida kirjeldati esimest korda eelmises peatükis, ning suunab lugeja võimalike surnuaiajuhtumuste juurest uuesti olevikusituatsiooni ja tuppa, milles neljas peatükk algas. Kui lugeja pöördub nendes versioonides selguse saamiseks tagasi neljanda peatüki algusesse, on selle esimene lõik muutunud järgnenud teksti mõjul kaheti mõistetavaks:

Jah, on tõsi, et käisin oma suguseltsi haudu otsimas. Olin tookord viiekümne nelja aastane ja esimest korda tekkis tungiv tarve rääkida vanatädiga, kes olevat olnud nõid. Nii ütles mulle ema, kui ta veel minuga rääkis. (Mihkelson 2001: 40)

Viimane lause võimaldab lõigust aru saada kahel moel. „Nii ütles mulle ema” ei pruugi enam viidata ainult teise lause lõpule - et vanatädi olevat olnud nõid -, vaid kogu lõigule, millisel juhul käis haudu otsimas ema, mitte tütar, nagu võiks eeldada minavormist. Sellisel juhul oleks kogu ülejäänud episood esitatud ikkagi ema, mitte tütre perspektiivist. Mihkelsoni poeetika mõistmise seisukohast ei ole peamine selgust saada, kes siis ikkagi päriselt surnuaial käis. Kaks peatükki esitavad tervikliku episoodi minajutustaja (või peategelase) retkest surnuaiale, kuid jutustaja perspektiiv näib olevat lõhestatud kahe lepitamatult erineva vaatepunkti vahel ning lõhestatus ise ongi kujutamise objekt. Tuba, kus kaks tegelast kohtuvad, ongi mõnes mõttes see vähene tugi, mida nende kohtumise stseen konkretiseerumiseks vajab.

Eelnevad analüüsid näitavad, et nii harilik mimesis'e kategooria nagu ruumi kujutamine võib jutustuse mitmetimõistetavuse mõjul hakata osutama pigem raskesti piiritletavale oleviku-stseenile. See ei tähenda, et lugemine suubuks halvavasse määramatusse: hägustub üksnes Jamesoni mõistes jutustuse kui individuaalsete saatuste aeg. See aeg saab pigem objektiks, mida tegelaste kohtumise olevikulises stseenis rekonstrueeritakse. Olevikuline stseen, milles toimub mineviku uurimine või isegi selles kokkuleppimine, muutub napi, vihjelise ja täpse kirjelduse mõjul aga aina reaalsemaks. 


\section{Sündmus ja stseeniline kujutamine}

Mihkelsoni poeetika stseenilisus saab selgemaks, kui proovida seda kirjeldada klassikalise narratoloogia põhimõistete, jutustuse aja ja jutustamise ehk diskursuse aja terminites. See tähendaks pidevat nende kahe aja vahelise vastavuse otsimist ja niisuguste kategooriate nagu prolepsis, analepsis, metalepsis aina peenemat eristamist. Ent just selliste vastavuste otsimine ei ole Mihkelsoni loomingu puhul viljakas. See ebakõla on ühelt poolt kontseptuaalset laadi, kuna jutustamise ja jutustuse aja suhete analüüs nõuab sellele eelneval tasandil jutustuse aja stabiilsust, mida Mihkelsoni romaanid ei paku ja mille puudumine näibki olevat Mihkelsoni teoste keskne probleem. Romaani narratiivsena käsitleva strukturalistliku meetodi ja Mihkelsoni romaanide fragmentaarsuse vaheline kontseptuaalne sobimatus märgib ühtlasi kirjandusloos poeetilist nihet suhteliselt stabiilset jutustust sisaldavalt realismilt stseenilise dominandiga modernistliku romaani poole. Strukturalistliku mudeli piiratust mööndes võib siiski metodoloogiliselt eeldada, et mingisuguse ajaskeemi pakuvad lugejale ka Mihkelsoni fragmentaarsed romaanid oma ebausaldusväärse jutustajaga ning samuti on võimalik otsida neist tekstidest sündmusi.

Mihkelsoni romaanide iseäranis staatiline edenemisviis on esimesi tunnuseid, mis lugemisel silma torkab. Jutustajahäälel näib olevat lõputult aega, et eritleda võimalikult pikkamööda kõikvõimalikke asjaolusid, mille tähtsuse hierarhia pole sugugi selge. Sündmused suure tähega, mis peaksid moodustama faabula, paistavad pigem tõenäosustena väikestes fragmentides, mida võiks Marju Lauristini (2018: 247) eeskujul nimetada mikrosündmusteks: kahtlustused, unenäod, näoilmed, haigussümptomid, meeleolumuutused jms. Rangelt võttes ongi „Katkuhaua” peamiseks sündmuseks minajutustaja kohtumine Kaataga ja tutvumine tema minevikuversiooniga. Mitmed kohad romaani lõpuosas panevad kahtluse alla, kas minevikuversiooni teadasaamine pakub vähimalgi määral lahendust tegelastele ja lõplikku tähendust jutustusele. Sama kehtib „Ahasveeruse une” kohta: teose moodustavad ühelt poolt käigud kodukülla ja kohtumised Vilma ning Kaarliga, teiselt poolt püsiv segadus ja skepsis selle suhtes, mis peaks olema nende kohtumiste tulemus. Nii ongi Mihkelsoni romaanide ranges mõttes sündmusi väga raske määratleda. ${ }^{8}$ Sündmuslikkus tuleb aga esile metatasandil. Kohati spekuleerib minajutustaja selle üle, kuidas mõni tegelane, nt Kaata, sündmustest mõtleb:

See tähendab, et Kaata mõtleb, kus ta selle või teise sündmuse toimumise ajal oli, kas ta on õigest kohast sündmust otsinud. Kui koht leitud, tuleb arvesse (mängu) aeg. Vahel on vastupidi: aeg osutab kohale, kuid nende kunagise seotuse ja sobimatuse tunde taastamine ja kättesaamine on ilmvajalik. Alles siis hakkab sündmus enesest märku andma. (Mihkelson 2007: 176-177)

Kaata on niisiis keegi, kes õieti ei te a, kes ta on, ja kohandab oma identiteeti vastavalt sellele, kuidas minajutustaja teda küsitleb. Peamine probleem Mihkelsoni

\footnotetext{
${ }^{8}$ Sündmuslikkusest teistsuguses tähenduses kui Mihkelsoni luule ühest püsivast omadusest kirjutab Hasso Krull (2016: 308).
} 
jutustajahääle jaoks ongi sündmuse hoomamise võimatus: „Sündmus on nagu vesi, piirjooned ei anna end kätte, ka kirjapartnerid ei seisa paigal, muutuvad ja reageerivad, nii et nendega kohtudes kaduvat tal pind täiesti jalgade alt" (Mihkelson 2001: 39). Kõige ilmekamalt, samuti vee metafoori abil, ja lausa väikese manifesti kujul väljendub Mihkelsoni sündmusekäsitus lühijutus „Lein”:

Mõnda sündmust või inimest tuleb mõista kolmveerandpöördes, h e t kel, mil t o i mumist on veel võimalik tagasi keerata ning sündmuse nägu kõhkleb justnagu viimases heitluses: kas siia või lõpuni. Kui siia, siis valguvad juba selgesti nähtaval olnud jooned tagasi, kuni vilksatab embrüo kortsus vanainimesenägu nagu algava lainetuse punktiks vaibuvad ringid; kui lõpuni, siis võib juba nimest kõnelda. (Mihkelson 1996: 133, minu sõrendused - I. O.)

Siia on koondunud Mihkelsoni proosa poeetika tuum: olevikusituatsioonis valitseb otsustamatus ja sündmusi ei ole veel nimetatud. „Algava lainetuse punktiks vaibuvad ringid” ja „embrüo kortsus vanainimesenägu” märgivad täielikku määramatust, millest paratamatult midagi alustatakse ja millesse on alati oht tagasi langeda. Kui aga „sündmuse nägu” avaneb lõpuni, tähendab see, et kirjutamise ja uurimise objekt on sisenenud ajalukku ja muutunud nimeks. Et lõik algab viitega sündmusele või inimesele, siis tähendab „lópuni” minek ka inimese saatuse valmis saamist Sartre’i ja Jamesoni mõistes, millele osutasin artikli sissejuhatuses. Jutustuse mineviku-olevikutuleviku telje aeg tähistab ühtlasi sündmuse kujutamise lõppu, valmissaamist. Mihkelsoni poeetika keskendub aga olevikule, kui inimene (või tegelane) on veel vaba ja keset valikusituatsiooni interpersonaalseid vastuolusid. ${ }^{9}$ Mõne harjumuspärases tähenduses sündmuse võimalikult tõe- või detailitruu kujutamine polegi Mihkelsoni eesmärk. Tema kujutamise objektiks on pigem fenomenoloogiline intersubjektiivne foon, mille alusel moodustuvad kokkuleppelised inimeste saatuste ja ühtlasi nn ametlike ajalugude lood (mõlemad on Sartre’i ja Jamesoni vaimus lineaarsed, minevikuoleviku-tuleviku teljel kulgevad). See toob kaasa ambivalentsuse ja pinge juba lause tasandil, milles Mihkelson rõhutab tihti erinevate subjektipositsioonide segunemist. Näiteid leidub romaanis „Korter”, mille peateemaks on sunnitud ühiselu:

Tema, keda polnud enam olemas, lahustus minalistesse kirjeldustesse, võõrastesse eludesse, otsides visalt ja visalt ühte ja ainsat mina, kaotatud mina. (Mihkelson 1985: 21)

Nad kohtusid korteris, kuigi olid kokku puutunud varem. Nende meeleolud segunesid nagu ihuhigi pärast pikka päevatööd. (Mihkelson 1985: 6)

Mõnikord väljendub personaalsuse-eelne seisund oksüümoronlikus kujundis: „Juhan on Martini tagasitõmbumise esileküündiv tipp” (Mihkelson 1985: 122). Juhan ja Martin ei ole selle lause järgi mitte autonoomsed tegelased, vaid pigem

\footnotetext{
${ }^{9}$ Lugude kirjutamisele vastuseisust ja oma modernistlikest eeskujudest proosakirjanduses on
} Mihkelson kõnelenud intervjuus Erik Linnumäele (Mihkelson 2019: 49-63). 
peategelase Ada isedust alal hoida aitavad stiimulid, ühe aina korduva mustri kaks omavahel seotud punkti. Selliste lausete mõistmiseks on oluline tõdeda, et neid ei saa omistada ühe selgelt eristuva tegelase teadvusele. Nii ei pruugi nendevahelisi suhteid aduda ei Ada ise ega ka Juhan või Martin. Ometi moodustab niisugune kirjeldus ühe impersonaalse killu terviklikust representatsioonist, mida romaan „Korter” esitab. Sündmuse peitumine paljude mikroskoopiliste täpsuste taha võib olla ka üks põhjusi, miks Mihkelsoni proosa mõjus algul „mudellikult”, mõne ainult autorile teada oleva teesi seletamisena (Veidemann 1987: 118). Kui naasta artikli sissejuhatuses püstitatud stseeni ja jutustuse vastanduse juurde, siis ongi niisuguse mulje tähtsaim põhjus romaanis domineeriv olevikuaeg, mis kipub jutustuse lõimi pidevalt neelama: sündmus on kas juba toimunud või alles toimumas, lugejale näidatakse ainult fragmente neist suhetest, mis on kas selle sündmuse tulemuseks (kui see on juba toimunud) või tingimuseks (kui see alles hakkab toimuma).

Siinse analüüsi täpsustuseks möönan, et igas Mihkelsoni proosateoses ei leidu niisugust stseenilise kujutamise impulssi võrdsel määral. Mihkelsoni loomingu arengukaare tulemuseks on eeskätt „Ahasveeruse une” ja „Katkuhaua” terviklikkus ja suurim impersonaalsus ja olevikulisus. Umbisikulisuse olulisim võte on jutumärkidest loobumine - just jutumärgid on vahend omavahel seguneva kõne ja diskursuse sidumiseks kindla isiku või häälega. Juba esikromaan "Matsi põhi” (1983: 5-93) algab paarileheküljelise metanarratiivse arutlusega tegelase ja kirjutava Mihkelsoni vahekorra üle, kuid romaani jätkudes jutustab peategelane Mari Kask oma lugu üsnagi üheselt mõistetaval ja põhjuslikul viisil, mis hoiab alal nii tema isikut kui ka ju t u st u st. Sama kehtib romaani „Kuju keset väljakut” (1983: 94-198) kohta, mis on Mihkelsoni kõige lineaarsem ja ainus domineerivalt kolmandas isikus ühe peategelasega romaan.

\section{Kokkuvõte}

Artikli eesmärk oli uurida, kuidas sobituvad Ene Mihkelsoni romaanid modernistliku romaani poeetika ühe keskse probleemi konteksti, milleks on olevikulise ehk stseenilise kujutamise domineerimine jutustuse üle. Mihkelsoni romaanide eritlemine näitab, et jutustuse nõrgenemist representatsiooni dünaamikas ei saa seletada pelgalt kirjelduse terminiga, mis kätkeks visuaalsust ja kehade väliskuju. Mihkelsoni romaanide stseeniline poeetika ei tulene iseäranis kirjeldamisest, vaid pigem jutustuse killustamisest erinevateks isikuteks, aegadeks ja kõneviisideks. Perspektiivide paljusus ja segatus suunab teoste dominandi selgelt väljajoonistatud tegelastest ja jutustusest eemale olevikulise stseenilisuse poole.

Mihkelsoni romaanide teemaks on Teise maailmasõja järgses Eestis toimunud terror ja sellele osutatud vastupanu, mida ametlik võim kirjeldas illegaalsena. Teoste tuumstseen kujutab selles ajaloolises olukorras sündinud keerulist suhetevõrgustikku, kokkulepete, reetmiste ja saladuste põimingut, milles on minajutustajal peaaegu võimatu leida kindlaid vastuseid. Tuumstseeni üheks poeetiliseks võtteks on mäng asesõnadega „Ahasveeruse unes”; nii selles kui ka „Katkuhauas” domineerib 
pidev siirdeline naasmine jutustuse minevikulõimedest olevikku, milles toimub reflekteerimine juhtunu üle. Nende võtete tulemuseks on sündmuste hägustamine äärmuseni ning asendumine arutlusega sündmuse võimalikkusest. Mihkelsoni poeetika kätkeb tegelaste, elulugude ja sündmuste ülesehituse radikaalset poolelijäetust, püüet hõlmata tervikusse võimalikult palju fragmente enne nende väljakujunemist, mis tähendaks sündmuste muutumist ajalooks ja sellega kaasnevat isikute moraalset hukkamõistu, kuid suleks võimaluse mõista ajaloosegmendi keerukust. Stseeniline poeetika on ühitatav arusaamaga (Laanes 2009: 157-229), et Mihkelsoni hilisem romaanilooming kätkeb immanentset kriitikat sajandivahetuse Eesti ajalooteadvuse kohta. Selle kriitika nähtavaks saamine ongi võimalik (peale autori uurimistöö ja isikliku kogemuse) suuresti stseenilisuse, mitte aga narratiivse kujutamise kaudu. Mihkelsonlik stseenilisuse poeetika ei keskendu eriti hinnangutele ja võimaldab reflekteerida ajaloolise kogemuse afektiivse külje üle, mis on reaalne, kuid kõikvõimalikes ametlikes dokumentides ja narratiivides halvasti üles märgitud. Niisuguse poeetika saavutuseks on traumaatilise ajaloosegmendi kujutamine, laskumata lihtsustustesse ja melodramaatikasse.

Artikli valmimist on toetanud Haridus- ja Teadusministeeriumi projekt PRG636 „Eesti siirdekultuuri arengumustrid (1986-1998)"

\section{KIRJANDUS}

Abott, H. Porter 2009. Narrativity. - Handbook of Narratology. Berlin-New York: Walter de Gruyter, lk 309-329.

Aristoteles 2003. Luulekunstist (Poeetika). (Keele ja Kirjanduse raamatusari 4.) Tlk Jaan Unt. Tallinn: Keel ja Kirjandus.

Breger, Claudia 2017. Affect and Narratology. - The Palgrave Handbook of Affect Studies and Textual Criticism. Toim Donald R. Wehrs, Thomas Blake. Palgrave Macmillan, lk 235-257.

Castle, Gregory 2015. Introduction. Matter in motion in the modernist novel. - A History of the Modernist Novel. Toim G. Castle. New York: Cambridge University Press, lk 1-34.

Eysteinsson, Astradur 1990. Realism, modernism and the aesthetics of Interruption. A. Eysteinsson, The Concept of Modernism. Ithaca-New York-London: Cornell University Press, lk 179-241.

Genette, Gérard 1983. Duration. - G. Genette, Narrative Discourse. An Essay on Method. Ithaca-New York: Cornell University Press, lk 86-113.

Genette, Gérard 2018. Jutustuse piirid. - G. Genette, Tekstist teoseni. Valik esseid. (Avatud Eesti raamat.) Tlk Anti Saar. Tallinn: EKSA, lk 65-84.

Hennoste, Tiit 2003. Mahasalgamise maa ajalugu. - T. Hennoste, Eurooplaseks saamine. Kõrvalkäija altkulmupilk. Artikleid ja arvamusi 1986-2003. Tartu: Tartu Ülikooli Kirjastus, lk 276-280.

Jameson, Fredric 2013. The Antinomies of Realism. London-New York: Verso. 
Kaus, Jan 2020. Kaos ja mälu. - Jalutuskäigud ja kohvijoomised. Kõnelusi Madis Kõivust. (Collegium litterarum 26.) Koost ja toim Aare Pilv. Tallinn: Underi ja Tuglase Kirjanduskeskus, lk 49-56.

Kern, Stephen 2011. The Modernist Novel: A Critical Introduction. Cambridge: Cambridge University Press.

Klauk, Tobias; Köppe, Tilmann 2013. Telling vs. showing. - The Living Handbook of Narratology. Toim Peter Hühn, John Pier, Wolf Schmid, Jörg Schönert. Hamburg: Hamburg University. http://www.lhn.uni-hamburg.de/node/84.html (22. V 2020).

Krull, Hasso 2016. Redel varemete kohal. Ene Mihkelsoni allegooriline poeetika. - Ene Mihkelson, Kõik redelid on tagurpidi. Valik luuletusi 1976-2010. Koost H. Krull. Tallinn: Eesti Keele Sihtasutus, lk 305-330.

Laanes, Eneken 2009. Lepitamatud dialoogid. Subjekt ja mälu nõukogudejärgses eesti romaanis. (Oxymora 6.) Tallinn: Underi ja Tuglase Kirjanduskeskus.

Lauristin, Marju 2018. Ikka Mihkelsonist mõeldes - tekstiväliselt. - Looming, nr 2, lk 246248.

Lewis, Pericles 2011. Introduction. - The Cambridge Companion to European Modernism. Toim L. Pericles. New York: Cambridge University Press, lk 1-10.

Mazzoni, Guido 2017. Theory of the Novel. Cambridge-Massachusetts-London: Harvard University Press.

Mihkelson, Ene 1983. Matsi põhi. Tallinn: Eesti Raamat.

Mihkelson, Ene 1985. Korter. Tallinn: Eesti Raamat.

Mihkelson, Ene 1996. Surma sünnipäev. Novelle ja laaste. Tallinn: Tuum.

Mihkelson, Ene 2001. Ahasveeruse uni. Tallinn: Tuum.

Mihkelson, Ene 2005. Kirjanikku usutelles. Vahendanud A. Merilai. - Päevad on laused. Ene Mihkelson. Tartu: Tartu Ülikooli Kirjastus, lk 125-132.

Mihkelson, Ene 2007. Katkuhaud. Tallinn: Varrak.

Mihkelson, Ene 2019. Vaba inimese tunne. Vestlused Ene Mihkelsoniga. Tallinn: EKSA.

Ojam, Indrek 2020. Argimütoloogia kui Mati Undi poeetika lähtekoht. - Keel ja Kirjandus, nr 4, lk 295-312.

Ojam, Indrek; Tomberg, Jaak 2016. Stseenilise oleviku mõjujõust kirjandusliku realismi esteetikas. - Keel ja Kirjandus, nr 4, lk 281-298.

Rein, Eva 2010. Joy Kogawa „Obasan” ja Ene Mihkelsoni „Ahasveeruse uni” kui ilukirjanduslikud traumanarratiivid. - Jutustamise teooriad ja praktikad. Koost Marina Grišakova. Tartu: Tartu Ülikooli Kirjastus, lk 205-224.

Ricoeur, Paul 1990. Time and Narrative. Tlk Kathleen McLaughlin, David Pellauer. ChicagoLondon: University of Chicago Press.

Ryan, Marie-Laure 1992. The modes of narrativity and their visual metaphors. - Style, kd 26, nr 3, lk 368-387.

Ryan, Marie-Laure 2006. Semantics, pragmatics and narrativity: A response to David Rudrum. - Narrative, kd 14, nr 2, lk 188-196.

Ryan, Marie-Laure 2007. Toward a definition of narrative. - The Cambridge Companion to Narrative. Toim David Herman. Cambridge: Cambridge University Press, 1k 22-36.

Sakova, Aija 2018. Ahasveeruse tunnistus. Kirjanduslik palverännak kui eetiline kohustus Ene Mihkelsoni „Ahasveeruse unes”. - Keel ja Kirjandus, nr 4, lk 285-296. 
Sakova, Aija 2020. Mäletamise poeetika. Ene Mihkelsoni ja Christa Wolfi romaanid lähivaates. Tartu: Tartu Ülikooli Kirjastus.

Sarapik, Virve 2005. Võõras mets. Ene Mihkelsoni proosast. - Keel ja Kirjandus, nr 9, lk 728-734; nr 10, lk 808-817.

Sha, Richard C. 2017. The turn to affect: emotions without subjects, causality without demonstrable cause. - The Palgrave Handbook of Affect Studies and Textual Criticism. Toim Donald R. Wehrs, Thomas Blake. Palgrave Macmillan, lk 259-278.

Sova, Henrik 2020. Semantiline pragmatism Ene Mihkelsoni proosas. - Keel ja Kirjandus, nr 7, lk 555-570.

Zhang, Dora 2013. Strange Likeness: Modernist Description in James, Woolf and Proust. Princeton: Princeton University.

Tammjärv, Maia 2012. Ebausaldusväärne jutustaja ja püsivalt ebausaldusväärne kirjandus. Magistritöö. Tartu Ülikooli kultuuriteaduste ja kunstide instituut.

Tomberg, Jaak 2011. Kirjanduse lepitav otstarve. (Heuremata.) Tallinn-Tartu: Tartu Ülikooli Kirjastus.

Tygstrup, Frederik 2007. Still life. The experience of space in modernist prose. - Modernism. (A Comparative History of Literatures in European Languages XXI.) Toim Astradur Eysteinsson, Vivian Liska. Amsterdam-Philadelphia: John Benjamins Publishing Company, lk 253-271.

Veidemann, Rein 1987. Ene Mihkelsoni seletused ja mõistatus. - Keel ja Kirjandus, nr 2, lk 117-118.

Indrek Ojam (snd 1988), MA, Tartu Ülikooli doktorant eesti kirjanduse erialal (Ülikooli 16, 51014 Tartu), indrekojam@gmail.com

\section{Dissolution of storytelling and scenic representation in Ene Mihkelson's prose}

Keywords: modernist novel, description, scene, story, affect

In the study of the poetics of the modernist novel, one of the unifying topics is the decrease of coherent storytelling in the proportion of representation. At the same time, the modern literary process has brought up new images, which function in a similar way as the descriptions familiar from the realist tradition but are meant to be associated with elusive physical tensions characteristic of modern society. According to Fredric Jameson the starting point of this development is in Gustave Flaubert's literary innovations, while Jameson's definition of modernism largely rests on an increasing domination of scene over story.

The aim of the article is to explore the above tendency in the prose works of Ene Mihkelson. Mihkelson's previous reception often points out the unreliability of the narrator and a certain fuzziness of character identities, as well as of the times when this or that story is told and of other boundaries in the text. The present analysis 
attempts to demonstrate how the vagueness or ambiguity of narration in her novels Katkuhaud (Plague Grave, 2007) and Ahasveeruse uni (The Sleep of Ahasuerus, 2001) gives rise to scenic images dominated by the present. The most important episodes of these two novels are dialogues between the main character and her senior relatives mainly discussing the incidents that happened between the Forest Brothers in Estonia after the Second World War. According to Mihkelson's poetics the reader gets a realistic enough description of the affective results of past events imprinted on the mind of the protagonist, without, however, being told the whole stories. In addition, Mihkelson's texts include meta-level discussions on the possibility of an adequate representation of historical experience, which I have also tried to integrate into my interpretation. One of the reasons why the poetics of Mihkelson's prose in dialogue with Estonian cultural and historical memory seems to have such a conciliatory effect is her focusing on affective and scenic credibility at the cost of a narrative perhaps too clear and unambiguous.

Indrek Ojam (b. 1988), MA, University of Tartu, doctoral student in Estonian Literature (Ülikooli 16, 51014 Tartu), indrekojam@gmail.com 